\title{
Paul and Africa?
}

Author:

Jean-Claude Loba-Mkole ${ }^{1,2}$

Affiliations:

${ }^{1}$ Translation Consultant

United Bible Societies,

Nairobi, Kenya

${ }^{2}$ Department of New

Testament Studies,

University of Pretoria,

South Africa

Note:

Dr Jean-Claude Loba-Mkole

is participating as research associate in the project

'Hermeneutics and Biblical

Theology', directed by Prof

Dr Andries G. van Aarde,

Honorary Professor at the

Faculty of Theology of

the University of Pretoria,

South Africa.

Correspondence to:

Jean-Claude Loba-Mkole

email:

Imkole@ubs-africa.org

Postal address:

PO Box 42 726-00100

Nairobi, Kenya

Dates:

Received: 04 June 2010

Accepted: 11 Sept. 2010

Published: 07 June 2011

How to cite this article:

Loba-Mkole, J.-C., 2011

'Paul and Africa?', HTS

Teologiese Studies/

Theological Studies 67(1),

Art. \#888, 11 pages. DOI:

$10.4102 /$ hts.v67i1.888

(C) 2011. The Authors Licensee: OpenJournals Publishing. This work is licensed under the Creative Commons Attribution License.
The relationship between Saint Paul and the continent of Africa has never been a significant point of discussion in the New Testament studies. The same can be observed about other continents, even if the study of the Pauline corpus touches on some countries of Europe and the Middle East. The present article was triggered by the invitation of the Catholic Church to celebrate the 3rd millennium of Paul's birthday during the period of June 2008 - June 2009, which was declared as the Year of Paul all over the world. It raises and discusses the question of relevance of Paul to Africa and vice versa in the light of intercultural exegesis.

\section{Introduction}

The present study aims at initiating a constructive dialogue on the relationship between Paul and the continent of Africa. It presupposes that the Pauline corpus is relevant to Africa and vice versa. The 3rd millennium anniversary of Paul's birthday has been commemorated in the Church by many Eucharistic celebrations, talks and writings from all the corners of the world. Paul is considered as the New Testament (NT) theologian par excellence. He is able to address different issues and situations in a very considerate way and at the same time allows the reader to 'see most clearly the character of NT theology as something alive and moving' (Dunn 2009:14).

The definition which the Second Special Assembly for Africa of the Synod of Bishops (Vatican 04-25 October 2009) ascribes to the meaning of evangelisation echoes a Pauline understanding of his ministry:

Evangelisation consists in bearing witness to Christ in the power of the Spirit through life and then by word (Evangelii Nutiandi, 21), in a spirit of openness to others, respect and dialogue with them, concerning Gospel values.

(Proposition 34 of the Second Special Assembly for Africa of the Synod of Bishops)

Indeed, Paul was sharing his theological views about Gospel values which were challenged or needed in particular contexts. What can Africa learn from such views and what can African contexts contribute to Pauline thoughts? This is the issue which the present study wants to explore using a biblical intercultural method. I have applied this approach elsewhere (see LobaMkole 2006, 2007, 2010). It consists of a constructive dialogue between a biblical original culture, a traditional Church culture and a contemporary culture. Each of these three cultural entities or 'cultural orientations' is granted its own epistemological privilege. The biblical original culture is given its epistemological privilege because of the canonicity of its texts, whilst the traditional Church culture deserves it due to its elderliness compared to the contemporary culture. The latter, in turn owes its epistemological privilege for being alive in blood and flesh with the responsibility of connecting the past, present and the future. The originality of the intercultural biblical exegesis resides in these three epistemological privileges, which enable the cultural entities to contribute equally and yet distinctively in the process of a constructive dialogue. In this particular study, Africa features both as a contemporary culture and as a Church culture, whereas Paul stands for the original biblical culture. I will first focus on Africa and Paul, before proposing or inventing the points of agreement between them. The expression 'inventing the points of agreement' reflects the fact that 'any intercultural communication is always transgressive, innovative, subject to bricolage' (Binsbergen 2003:516), because the genuine differences can only be reconciled in dialogue, love, seduction, trade, diplomacy, therapy, ritual, ethnography and intercultural philosophy in an innovative way that is not compellingly imposed by any of the parties involved (Binsbergen 2003:516).

\section{Africa}

\section{Africa as geographical and multi-cultural entity}

In this study, Africa is understood as a geographical and multi-cultural entity, which shapes the interpretive skills of people associated with it in terms of origin, naturalisation, residence or profession. Africa is in fact a continent of great contrast and diversity (McNulty 1995:13). It can rightly be called a 'rainbow continent' because of the different skin complexions of its people (Arab people, Black people, White people, Indians and Coloured people, amongst many others). 
However, this diversity has sometimes led or misled people to cut off Maghreb countries from Africa and ascribe them to the Mediterranean part of Europe (Isichei 1995:13), if not to the Middle East in Asia, or both. The idea of allocating North Africa to Mediterranean Europe most probably originated from the period of the Roman Empire. During the second triumvirate (43 BCE), Africa was given to Marcus Lepidus whilst Marcus Antonius was in charge of the East and Gaius Octavius of Italy, Gaul and Spain. About 19 centuries later, a new geographical-political map of Africa was designed at the Berlin Conference (1884-1885) and Africa was divided amongst the then most influential powers (France, Britain, Belgium and Portugal). Most of West Africa was granted to the French. The British took control of eastern and southern Africa. The Belgians acquired the territory of the Democratic Republic of Congo, Rwanda and Burundi, whilst the Portuguese got hold of Cape Verde, Mozambique and Angola. The majority of African countries became independent on paper in the 1960s. Presently, Africa is made up of 53 states and governments. The geo-political map of Africa inherited from the Berlin Conference remains almost the same, 50 years after the so-called political independences. Amazingly, even 8 years after the founding of the African Union (09 July 2002) the citizens of its 53 member states still need visas to cross many of their own internal borders.

A number of political, cultural and economical developments indicate that the notion of an African geographical map varies from one circle to another. Some African and non-Africans consider that Africa refers to the countries of people of colour (i.e. a derogatory use of Black skin complexion) located south of the Sahara Desert and north of the Limpopo River. These countries constitute a significant part of what is known as the commonwealth of poverty (McNulty 1995:13). Furthermore, Africa is currently known as a continent of ethnic, religious and political clashes where peace seems to be a rather scarce commodity. Ironically, this peace is safeguarded by those who fuel the conflicts to generate more income. In other terms, Africa or African equals Black skin colour and poverty for the majority of African natives, but lucrative business opportunities for the majority of those who are African by profession and their sponsors. Africa would certainly gain more stability if it could boldly start removing or demoting the causes of violence and poverty for the sake of a 'peace mentality' (Shorter 2005:349).

After the end of the Cold War, which divided Africa into two blocks (capitalists and communists), the most recent partition of Africa happened with the creation of the Mediterranean Union on 13 July 2008. This block strives to extend the European Union to North Africa like its ancestor, the Roman Empire, did with the same part of Africa. But, this development can also be regarded as a second extension of Africa to Europe, since the Cotonou Partnership Agreement of 23 June 2000 connected Africa to America, Asia and Europe through 79 African, Caribbean and Pacific states. I would propose that Africa leads in establishing another union like the Great Rift Valley Union (GRVU). The Great Rift Valley is the name given in the late 19th century by British explorer
John Walter Gregory to a continuous geological crack (valley) of approximately 6000 kilometers that stretches from Lebanon to Mozambique. It physically unites the following countries that would become members of GRVU: Lebanon, Syria, Israel, Jordan, Egypt, Saudi Arabia, Yemen, Soudan, Eritrea, Djibouti, Ethiopia, Somalia, Kenya, Uganda, Rwanda, Burundi, Tanzania, Congo (Democratic Republic), Zambia, Zimbabwe, Malawi and Mozambique. The Great Rift Valley is the cradle of human origins and developments punctuated by the transition from hunting to farming and then the invention of language and writing (cf. Futehally 2010:1). It also produced major belief systems such as African religions ('Africanism'), Judaism, Christianity and Islam. The creation and promotion of GRVU will certainly involve political decisions from the heads of state or governments together with the leaders of faith communities, business circles and scholarly bodies. On a scientific front, The Eastern Africa Journal of Humanities $\mathcal{E}$ Sciences and alike, as well as the Institute of Scripture Studies amongst others would become appropriate venues for discussing and documenting issues pertaining to this part of the world. The formation of the GRVU is urgent, as the area concerned is the most threatened by poverty (at least in the African part of the Valley), ethnic clashes, religious conflicts and by the effects of the climate change. The alarming impact of the climate is already perceptible:

The countries in the Great Rift Valley are expected to be the ones that will be the most affected by climate change in the coming decades. Historical climate records in Mozambique already show a warming of 1.1-1.6 degrees Celsius over the past 40 years. From 2040 to 2060, maximum temperatures are expected to increase by almost 3 degrees Celsius in the interiors. This will lead to more unpredictable rains, droughts, floods and uncontrolled fires.

(Futehally 2010:1)

Beside the degradation of the natural resources for climatic or even trade reasons, citizens from the African countries of the Valley have been the victims or perpetrators of inter- or intrastate wars and the survivors' purchasing power is reduced to less than \$1 per day. R. Draman (2003:5) rightly argues 'that poverty is both cause and consequence of conflict. The relationship is two-way: poverty leads to conflict and vice versa'. This is true of most African countries, as failure to maintain a reasonable standard of social welfare breeds insecurity, diseases, ills like corruption, hunger and thirst, drug-substance abuse, war militant gangs, suicide, fratricide or genocide, to name but a few.

Geographical and cultural boundaries of Africa are not clearcut. Africa is often associated with poverty, incompetence and Black skin complexion. Yet, Africa has wealth, skilled people and non-Blacks. Africa has its opportunities and challenges. Then, Africa is more of a mindset shaped from the worldview shared by the beholder. Still, this mindset can be reflected in the way that 'Africans' use the time, occupy the space, manage the people and value the natural resources. As a result, some salient features emerge from these ways of conducting business and become reference points for defining Africa, even if they can change for better or worse. 
To paraphrase Kwame Bediako (2001) and transpose his definition of culture to Africa:

Our Africa is our worldview. It is fundamental to our understanding of who we are, where we have come from and where we are going. It is everything in and around us that defines and shapes us in relation to the geographical and multicultural rainbow continent.

(Kwame Bediako 2001:2-11)

The geographical map of Africa comprises the area between Ras ben Sakka in Tunisia (the most northerly point) and Cape Agulhas in South Africa (the most southerly point) on one hand, and on the other hand the area running from Cape Verde (the westernmost point) to Ras Hafun in Somalia (the easternmost point). Africa has been and still is the centre of crosscurrents of world history; it is considered as 'the source of the earliest human biological and cultural developments and the point from which some of the most essential elements of human society and growth were derived' (Martin \& O'Meara 1995:6). The essential cultural elements derived from Africa includes, amongst other things, business activities (e.g. hunting and gathering, fishing, farming, livestock, herbal medicine and brewery), artistic endeavours (e.g. music, dance, sculpture and pyramidal constructions), weapon industry (e.g. spears, long bows and arrows), social institutions (e.g. political hierarchy, heterosexual marriage, initiation to adulthood) and religious beliefs.

Many of the traditional elements have survived in Africa up to now and each of them certainly has some bearing on the identity of Africa today, including the meaning of work and prayer, which are so dear to Paul. Paul was interested in establishing or visiting Church communities rather than just touring for business or leisure and it therefore seems appropriate to recall the situation of the Church in Africa, starting from apostolic times to the present days.

\section{Church in Africa}

Historically, Church presence in Africa is as old as the early Christian communities of the year $30 \mathrm{AD}$, because its roots go back to the very time of Jesus (cf. Mk 15:21) and that of the apostles. Some pointers can account for the African Christian communities during the apostolic times. First, the presence of Jesus' disciples from Cyrene in Jerusalem (Ac 2:10), Antioch (11:20-26) and Rome (Rm 16:13) is an indication for the existence of a potential Church in Cyrene. Second, the Ethiopian Eunuch would certainly have started a community of Jesus' disciples once he got back home after his baptism by Philip in Gaza (Ac 8:26-40). Similarly, when Apollos decided to go to Ephesus and Corinth to support Paul in proving from the Scriptures that Jesus is the Messiah, he would most likely have left a community of Jesus' disciples in Alexandria (Ac 18:24-28). In the subdivision of Church history in Africa, John Baur (2005:21) rightly starts the first period with the year $30 \mathrm{AD}$ :

- Christian antiquity in Northern Africa and its Horn (301500 AD)

- Christianity in the Ancient African kingdoms (1400-1800 $\mathrm{AD})$
- Foundation of Modern Christianity in Africa (1700-1900 AD)

- Rapid Growth of the Church in Africa (1900 AD to date).

After the apostolic times, the glorious Christian antiquity in Africa is celebrated for its martyrs (e.g. Felicitas and Perpetua), outstanding writers (e.g. Tertullian, Clement of Alexandria, Origen, Cyprian, Athanasius and Augustine of Hippo), church councils (especially the Third Council of Carthage which confirmed the canonical content the Christian Bible in 397 AD) and Scripture translations into the Coptic language, including the Bohairic and Sahidic dialects (Egypt) and into the Ge'ez language (Ethiopia). For the history of the Biblical canon, it is worth quoting the resolution of Carthage III verbatim, as found in the Codex Canonum Africanae Ecclesiae of 419 AD:

The Canonical Scriptures are these: Genesis, Exodus, Leviticus, Numbers, Deuteronomy, Joshua the son of Nun, Judges, Ruth, four books of Kings, two books of Paraleipomena, Job, the Psalter, five books of Solomon, the books of the twelve prophets, Isaiah, Jeremiah, Ezechiel, Daniel, Tobit, Judith, Esther, two books of Esdras, two books of the Maccabees. Of the New Testament: four books of the Gospels, one book of the Acts of the Apostles, thirteen Epistles of the Apostle Paul, one epistle of the same [writer] to the Hebrews, two Epistles of the Apostle Peter, three of John, one of James, one of Jude, one book of the Apocalypse of John.

(The resolution of Carthage III)

The four books of Kings include 1 and 2 Samuel, 1 and 2 Kings; the two books of Paraleipomena refer to 1 and 2 Chronicles; the five books of Solomon mean Proverbs, Ecclesiastes, Song of Songs, The Wisdom of Solomon and The Wisdom of Ben Sira, whilst the two books of Esdras imply Ezra and Nehemiah.

The Church presence in Africa moved from the Northern Africa and its corn to the rest of Africa with the arrival of Western missionaries in various countries and different periods of time. The first Christians in Sub-Sahara Africa is reported to be the Chief Mani of Soyo (Lower CongoKinshasa), who was baptised on April 03 in 1491 (Easter Sunday) and took the name Manuel, which was the first name of the cousin of Joâo II, the King of Portugal (Ndaywel è Nziem 1998:86). Church plantation flourished in ancient African kingdoms (1400-1800 AD), even though it stopped in some places and was resumed again later and continued without interruption in other contexts into Modern Africa (1700-1900 AD) with a considerable presence of Western missionaries.

The current Church in Africa is characterised by its remarkable growth in the number of Christians and that of the local clergy. In 1900, Christians were estimated to make up 9.2\% of the African population, whilst by 2025 they are estimated to reach $49 \%$ (633 million) of the African population. But the other side of the coin gives a different picture of Africa. As much as the current Africa is known as a constituent of the commonwealth of poverty, today's Church in Africa is also portrayed as the 'Church of the poor' (Orobator 2005:209). Nonetheless, Pauline letters continue 
to be fervently read in Africa during individual devotions, Bible study group meetings and Church services. Therefore, poverty might not be the only feature that defines Africa and the Church in Africa. One should not undermine the powerful role that Africa has been playing in the expansion of the Church ministries from the early period until today (cf. Ac 2:10; 8:26-40; 11:20; 1 Cor 3:5-9).

In a phenomenological sense, the term Church applies to different Christian communities like the Catholic, Orthodox, Anglican, Protestant, Evangelical, Pentecostal, Revival and African Independent Churches or Christianisme du terroir, which means 'Home based Christianity' (Kä Mana 2000:23,122). Josée Ngalula (1994:259-260) questions the accuracy of the expression 'African Independent Churches'. Nevertheless, each Church denomination faces epistemological and semantic challenges. How catholic is the Roman Catholic Church? How evangelical is the Evangelical Church? How pentecostal is the Pentecostal Church? How African and independent is the African Independent Church? Is the Roman Catholic Church the only Christian Catholic community, or the Evangelical Church the only evangelical, or the Pentecostal Church the only pentecostal, or the African Independent Church the only African and independent? Besides, each of these communities claims to belong to Christ. This is the main reason which leads each of them to consider itself as the or $a$ Christian Church. Therefore, the approach of ecumenical dialogue appears to have the chance of integrating a greater number of various and enriching views, experiences and challenges about the Church as shared by different communities (Mugambi 1995:196; Orobator 2000:36; Kä Mana 2000:40,212). I stick to an ecumenical understanding of the Church, which recognises and respects different Christian communities that identify themselves and are recognised as Disciples of Christ, People of God and Temple of the Holy Spirit (Küng 1992:134; Van der Watt 2000:438). However, it should be noted that my analysis is embedded in Roman Catholic tradition where the notion of Church also implies the communion with the Bishop of Rome, viewed as the successor of Peter to whom Jesus had entrusted his sheep (Jn 21:15-19).

The fundamental mission of the Church consists of witnessing Christ in terms of proclamation, fellowship and service. In Africa, this mission is specifically apprehended as inculturation, liberation, Church-as-family, innovation, reconstruction or life promotion. Charles Nyamiti (2007:222223) aptly summarises the different views of the Church by some African theologians. The Church is viewed as a 'new clan' (Waliggo), a 'mystery of superabundance of vitalforce' (Bujo), a 'new "harambee" community' (Wachira), an 'initiatory and cosmotheandric mystery or a community of mystical or spiritual in-laws in Christ' (Nyamiti), a 'new ujamaa community' (Onwubiko), or a 'family of God' (Fogliacco, Bishwende, Nyamiti, Orobator).

After describing Africa but before showing the mutual relevance between Paul and Africa, it is important to highlight some aspects of Paul's identity.

\section{Paul \\ Socio-historical background}

Paul was born in Tarsus (Ac 22:3, 6; 21:39) and died in Rome around 65-67 AD. The date of his birth is unknown, although it was most likely between 7 and $10 \mathrm{AD}$ or more inclusively during the 'first decade AD' (Fitzmyer 1990:1332). He acquired both his Jewish identity and Roman citizenship from his parents, who were not only Jews, but also Roman citizens (Ac 22:25-29; 16:37; 23:27). The Roman citizenship would have been granted to his parents because of their commendable job of making and supplying tents for the Roman soldiers in Tarsus. Paul himself might have learned the tent making skills from his own parents. Acts 23:16-35 mentions Paul's sister, whose son facilitated his escape from a death ambush laid by some Jews in Jerusalem. In terms of education, Paul was well trained in the Graeco-Roman rhetoric in both Tarsus and Jerusalem, or at least in one of these cities, as 'rhetors were found in all the great cities of the Roman Empire, especially in university towns like Tarsus and even in profoundly Jewish cities like Jerusalem' (Witherington III 1995:40). He studied the Jewish Law (especially the pharisaic traditions) at the feet of the great rabbi Gamaliel in Jerusalem (Ac 22:3), most probably after his initial training from his father in Tarsus, his home town (Du Toit 2007:14). Having become a rabbi (teacher), Paul started persecuting Christians, but the Risen Christ on the road to Damascus (between 30 and 36 AD) soon converted him. He had a vision of Jesus, who appointed him to preach the Gospel to both the Israelites and the Gentiles (Ac 9:15), but with more emphasis on the Gentiles (cf. Ac 22:21; 26:1923; Gl 1:16). Paul's commitment to his new mission led him to be hunted, mostly by the Jewish authorities in Jerusalem, but also in the Diaspora, where both Jewish and non-Jewish leaders wanted to arrest him. This may account for his escape from Damascus to Arabia (cf. Ac 9:23-25; Gl 1:17; 2:1), which also involved a threat by the Governor of this city, which was under the Nabatean King Aretas between 37 and 39 AD (cf. 2 Cor 11:32-33) (Crossan \& Reed 2004:31). During his sojourn in Arabia, Paul might have been exposed to many other cultures from the Middle East, African East Coasts and India, which were all connected by the trade of spices and incenses like frankincense, myrrh, cinnamon and cassia (Benjamin 2001:6,9). Some evidences from the New Testament indicate that Paul's acquaintance with Africa was mediated through his interactions with Apollos (1 Cor 3:5-6), Rufus and his mother (Rm 16:13), as well as through the Alexandrian ships which facilitated his arrival in Rome (Ac 27:5-6; 28:11-14). He is rightly considered as 'a meeting place and integrating point of a variety of influences' (Du Toit 2007:33) or 'confluence of ideas, motifs and practices of almost any provenance' (Engbert-Petersen 1995:16-17). Unfortunately, or perhaps fortunately, as some critics have indicated (Ramsay \& Wilson 2001:38-39; Van den Heever \& Scheffler 2001:144), Paul seems to have been disgraced by his parents after his conversion, to the extent that he could say in Philippians 3:8:

Indeed I count everything as loss because of the surpassing worth of knowing Christ Jesus my Lord. For his sake I have 
suffered the loss of all things, and count them as refuse, in order that I may gain Christ.

How then, did Paul relate to the Church of Christ?

\section{Paul and the early Christian Churches}

In the days of his youth Paul was not keen on the Church; he was more interested in persecuting Christians (cf. Ac 8:1; 22:5). But after his conversion, he became the most dedicated harbinger of the Gospel of Jesus Christ, the unbeatable advocate of the freedom in Christ (Ac 15:1-35; G1 5:13) and the master-builder of several Christian communities. After founding at least five significant Christian communities (Galatia, Philippi, Thessalonica, Corinth and Ephesus), he authored a minimum of seven authentic letters ( $1 \mathrm{Th}, 1 \mathrm{Cor}$, 2 Cor, Gl, Rm, Phlp and Phlm). Six other letters are attributed to him, even if their authenticity is disputed (Eph, Col, 2 Th, 1 \& $2 \mathrm{Tm}, \mathrm{Tt}$ ). He carried out three missionary journeys, which all started and ended up in Antioch (his home Church base), located in ancient Syria, currently Turkey. He took on the 4th and last journey as a prisoner from Jerusalem to Rome, where he had been longing to go and preach ( $\mathrm{Rm}$ 1:15). Paul's decision to appeal to Caesar (Ac 25:8-12) was most probably 'super-motivated' by the awareness of Jesus' command to his disciples to be his witnesses from Jerusalem until the end of the world (Ac 1:8), which some of them, like Peter, had managed to achieve by preaching the Gospel in Rome (Iersel 1998:35), the latter being regarded as the capital city of the world at that time. Jesus personally granted Paul's desire and he said, 'do not be afraid, Paul; you must stand before Caesar' (Ac 27:24). Indeed, Paul did stand before Caesar, but the most gratifying thing for him was to be there in Rome preaching, at his own expenses, the kingdom of God and teaching about the Lord Jesus Christ quite openly and unhindered (Ac 28:30-31). In all, Paul succeeded to create and maintain healthy, though sometimes controversial relations with the great Church centres of his time, such as Jerusalem (Ac 15:2; Gl 1:18), Antioch (Ac 11:25-18:22), Rome (Ac 28:23-28), with his co-workers mentioned in his letters and with his acquaintances of different backgrounds (e.g. the list in Rm 16:1-16).

Traditionally, Paul is known as an apostle; indeed his 'awareness of his place in God's purpose finds its most pointed expression in his understanding of himself as an apostle' (Beardslee 1961:79; see also McCant 1988:552). He is even viewed as the classical representative of the apostolate in the New Testament because he is the only apostle who is to some extent depicted in his apostolic position while the others leave no direct information concerning the manner of their apostolate (Rengstorf 1964:437). With the exception of Philippians, 2 Thessalonians and Philemon, Paul introduced himself in letters as apostolos [apostle] and his task was to evangelise. His apostolic exousia originated from God's call. This is evidenced by the phrase kletos apostolos [called to be apostle] (McCant 1988:552-553). However, whilst Paul sees himself as an apostle, Luke surprisingly never refers to him by this title:

The very vocation for which Paul lives and dies is denied him by Luke. He is, to be sure, an important missionary sent out from and living in complete accord with Jerusalem. But he is not an apostle equal with the Twelve.

(Crossan \& Reed 2004:29)

One might admit that for Luke, an apostle should be one of the 'Twelve' who were with the earthly Jesus. But, in Paul's view the 'apostolicity derives from revelation and vocation by the risen Lord' (Crossan \& Reed 2004:30). In this sense Paul was an apostle, having been commissioned by Christ to proclaim the Gospel.

According to Bruce J. Malina and John J. Pilch (2006), Paul's political message for his Israelite audience can be summarised as follows:

The God of Israel was on the verge of instituting an Israelite theocracy. The harbinger of this event was the act by which this God raised a person named Jesus from the dead, thus constituting him Lord and Messiah - all with a view to the forthcoming theocracy.

(Malina \& Pilch 2006:143)

Malina and Pilch (2006:14) argue that Paul's proclamation was meant specifically and exclusively for Israelites, especially those in the Diaspora. This exclusivist view is not convincing, because 1st century Judaism 'was constituted by a variety of groups who claimed Israel's traditions and symbols, coupled with varying interpretations thereof' (Craffert 2001:43). These interpretations included those generated by Jesus-group movement, which advocated a universalistic view of the salvation in the God of Israel, as already suggested by many prophets. Nevertheless, the universalistic view has to adjust to the fact that religion, politics and ethnicity were closely interrelated in the first century Mediterranean world. As a result, the Jesus-group movement of the second generation, as championed by Paul, claimed to be commissioned to proclaim a politico-religious message about the reign of the God of Israel, first to the Jewish ethnic group, but also to other tribes. This inclusive view is also exemplified by the gospel of Matthew which accommodates both a particularistic 'insider' trend (Mt 10:5-6) and a universalistic 'outsider' trend (Mt 28:16-20). Arguing against the view of discontinuity between the Israelite crowd and the gentiles in the gospel of Matthew, Andries van Aarde (2007:432) concludes that "the "history" of Jesus and the "history" of the church are included in Israel's history'. There is no need to portray Paul as an agent of change for the Jews alone. On the contrary, with his intercultural background as a born Jew and an accomplished Pharisee, a Roman citizen, a Hellenistic rhetor and a former Arabian resident for about 14 years, Paul was well placed to carry out his mission with both ethnic and universalistic tones. He was the most qualified intercultural mediator of the Gospel (Mulholland, Loba-Mkole \& Kitoko 2009:78; Du Toit 2007:392).

Paul earned his living through manual labour (see 1 Th 2:9; 1 Cor 4:12; 9:6; 2 Cor 11:27; cf. 2 Th 3:8; Ac 20:34-35). He occasionally received material assistance from Christian communities (see 2 Cor 11:9; Phlp 4:15-16; Rm 16:1-2, 23), but his 'stated missionary policy and practice' was to be self-supportive (1 Th 2:9; 1 Cor 9:12,15,18; cf. 2 Th 3:10-12) 
(see Still 2006:782). It is commonly agreed that the nature of Paul's manual labour was related to handicraft which included the making of tent-cloth from cilicium, [goat's hair] leather or both (see Murphy-O'Connor 1996:86-89 quoted by Still 2006:781). More interestingly, the tent-making craft was very appropriate for Paul's ministry, as he could carry it out whilst travelling around and visiting his communities. He could even make more friends amongst people of the same handicraft in different cities (see Aquila, Priscilla and associates in Ephesus, Corinth and Rome, amongst others). Nevertheless, Ronald F. Hock (1976:41-53, 1978:555-564, 1979:438-450, 1980) pointed out that tension developed between the Corinthians and Paul because of his refusal to set aside his tent-making business and become their client whom they would pay for preaching the Gospel to them (cf. 1 Cor 9:17-18). Furthermore, this business made him appear 'slavish' (cf. 2 Cor 11:7; see also 1 Cor 9:19-23) (see Hock 1978:559-561).

From a socio-historical perspective, Paul can be considered as an apostle and as an agent of change for the Jesus-group movement of the second generation, chosen by God to preach the Gospel of Christ to both the Jews in Diaspora and the Gentiles. He carried out his mission as a well trained Pharisee, a Hellenistic rhetor and an independent tentmaker totally committed to Christ, to whom he ultimately devoted his freedom and service. Paul's Jewish, Roman and Hellenistic backgrounds, as well as his Arabic and African acquaintances coupled with his personal experience with the Risen Jesus-Christ, Judeo-Christian communities and diverse socio-political institutions have made him the most qualified intercultural mediator of the Gospel. Any of his writings is already loaded with a set of original biblical and even extra-biblical cultures. His Church leadership experience is paramount: he maintained healthy links with the mother Church in Jerusalem and his Church base in Antioch; he founded new Churches and encouraged both the latter and the existing ones through his physical or epistolary presence; he finally managed to reach Rome, the capital city of the empire and there preached the Gospel.

Paul's multicultural background and his multifaceted Church leadership make him an authority that Africa should consult during this period of Church growth. In turn, Paul would surely be interested in African experiences of Church growth. Therefore, it is time to re-examine or invent areas of relevance between Paul and Africa or to reconcile them in the light of intercultural exegesis (cf. Binsbergen 2003:32; LobaMkole 2005:29, 2007:7).

\section{Invention of mutual relevance Relevance of Africa to Paul}

At a glance, Africa might seem to be irrelevant to Paul, given that he did not even bother to visit or address any African community of his time. It can easily be objected that Paul could not write to every part of the world. Nevertheless, Africa is a different case, because it has always been part of various transactions (human and capital) with Israel, Arabia and Europe, which Paul had all visited. Besides, since Paul was more accustomed to preach to nations of the Jewish Diaspora, one could expect him to connect more formally at least with the more vibrant African Jewish community of Alexandria or follow up on the Scripture experience in Ethiopia (cf. 1 Ki 10:1-13; 2 Chr 9:1-12; Ac 8:26-40). Is it then because of its irrelevance that Paul did not come or write to Africa? Probably not! The absence of Paul's visit or letter to any African community cannot be used as argument for deeming Africa as totally irrelevant to Paul.

Firstly, Paul's interactions with Apollos, who was similar to a representative of the Judeo-African community from Alexandria (Ac 18:24-27), proves the relevance of Africa to him. What Paul said about Apollos can be regarded as one important aspect which he would have wanted to highlight if he had had the opportunity to come or write to Africa. Paul recognises that some churches he had planted were watered by Apollos whilst God provided for their growth (1 Cor 3:5-6). Apollos was not just somebody hired for watering the churches, but a co-worker of Paul in the ministry of evangelisation in Corinth (1 Cor 3:8-9; 16:12).

Secondly, Paul expresses his regards to Rufus and his mother, greeting the first one as an 'eminent' or 'chosen' person in the Lord and the second one as his own 'mother' (Rm 16:13), probably owing to the hospitality she might have extended to Paul earlier on somewhere in the middle East. This high esteem or tenderness in which Paul held Rufus and his mother (Légasse 2002:952) is more plausible if they are members of the family of Simon of Cyrene who had carried Jesus' cross in Jerusalem (Mk 15:21). His two family members would have moved to join the Christian community in Rome where they became well known and were most probably mentioned by the author of the Markan Gospel and by Paul in his letter to the Romans. Although Simon and his other son Alexander are not mentioned in Romans 16:13, the probability of viewing the named ones as part of the same family cannot be dismissed as a 'curious coincidence, which in fact has little if any probative value' (Iersel 1999:33). In fact:

if the identification with the family of Simon of Cyrene is correct, there is also evidence of considerable mobility and thus a measure of economic power in their travels between Africa, Jerusalem, Rome, and somewhere in Paul's eastern mission areas.

(Jewett 2007:968)

Thirdly, Paul's arrival in Rome, which was motivated by his irresistible desire to preach the Gospel of Jesus in the capital city of the world of his time (Rm 1:15), was facilitated by two consecutive ships from Alexandria (Ac 27:5-6; 28:11-14). Besides, traditions about the God of Israel and the Gospel of Jesus of which Paul had become the herald were known by Ethiopian pilgrims even before Paul's encounter with Apollos or Rufus and his mother.

Fourthly, there were Africans from Egypt and Libya (Cyrene) who witnessed the birth of the Church on Pentecost Day 
in Jerusalem (Ac 2:10). People from Cyrene became more prominent, as they were represented by Simon in carrying the cross of Jesus (Mk 15:21); by those present on Pentecost Day (Ac 2:10) and by others who joined in the preaching of the Gospel of Jesus in Antioch (Ac 11:20-26), the home Church of Paul where the latter might have most likely met Rufus and his mother.

Fifthly, it is in Tunisia (Africa) that the Third Council of Carthage confirmed the list of the canonical books of the Old and New Testaments including the 13 letters attributed to Paul in 397 AD.

Africa has proved to be relevant to Paul through some human or material resources as Apollos, Rufus and his mother, other preachers from Cyrene who arrived in Antioch after the Pentecost in Jerusalem, and the 'Alexandrian' ships that facilitated the journey of Paul to Rome. But, is Paul relevant to Africa? This question will be answered through an analysis of how Paul's recommendation for praying and working appeals to Africa.

\section{Relevance of Paul to Africa}

There are certainly many aspects in which Paul might be relevant to Africa. For instance, in Romans 8:18-21 Paul states that:

The creation waits with eager longing for the revealing of the sons of God ... the creation itself will be set free from its bondage to decay and obtain the glorious liberty of the children of God.

This statement links the future glory of the children of God together with that of all the creation; it can make a valuable point of reference for the discussions on environmental degradation in African countries that are most affected by the global warming, particularly those in the Great Rift Valley Region. In view of the limits of this article, I choose to deal just with two other areas where Paul seems equally relevant to Africa, namely the appeal for combining work and prayer (i.e. contemplative action or active prayer) in order to reduce poverty (cf. 1 Th $2: 9 ; 3: 10$ ) and the plea for reconciliation in order to demote conflicts (cf. 2 Cor 5:20). Poverty and conflict are interrelated and have a negative impact on natural resources. Therefore, proper strategies for preventing poverty and conflict can certainly have a positive ecological impact.

\section{The rhetoric of working and praying unceasingly (1 Th 2:9; 3:10)}

Africa was important to Paul and a key message from his very first letter recommends his audience to strive in constant prayer and work (1 Th 2:9; 3:10); this seems to be equally relevant to Africa.

The literary structure of 1 Thessalonians consists of a prescript and greeting (1:1), thanksgiving and praise (1:2-3:13), exhortations and instructions (4:1-5:28). These exhortations can be subdivided in sections pertaining to Christian conduct (4:1-12), the coming of Christ (4:13-5:11) and the final words and greetings (5:12-28). One might also take into account the display of a rhetorical structure (cf. Segbroeck 2004; Jewett 1986; Porter 1997:547-551; Hughes 1990) which includes some key sections such as an exordium (1:1-10), a narratio (2:1-12), a vituperatio (2:13-3:13), a probatio (4:1-12), an inclusio (4:13$5: 11)$, paranesis $(5: 12-24)$ and a peroratio $(5: 25-28)$. Thought these critics do not mention it, Paul's main argument or propositio seems to deal with thanksgiving, which is repeated in various rhetorical sections of the letter $(1: 2 ; 2: 13 ; 3: 9 ; 5: 18)$.

After the prescript, 1 Thessalonians connects with the words of thanksgiving and praise (1:2-3:13) that are suitable for this more developed section of exordium (especially 1:2-10) and follows the words of introduction and greetings in 1:1. Normand Bonneau (2005:437-448) shows how this section fits as a narrated story, discourse and narration, but fails to read it in the light of the thanksgiving motif. The first sentence of this exordium covers five verses (1-5) which spell out the reason for the thanksgiving. Firstly, Paul thanks and praises God because of the work of faith [ergou tès pisteôs], the labour of love [kopou tès agapès] and the steadfastness of hope [hupomonès tès elpidos] amongst the Thessalonians (2-4; cf. 1 Cor 13:13). Secondly, he bursts into thanksgiving and praise because God had chosen the Thessalonians to hear the Gospel preached in power and in the Holy Spirit (4-5). As a result, Paul is more satisfied and delighted, realising that the Thessalonians had even become imitators [mimètai] of himself and Jesus as well as an example [tupon] of conversion for all believers in Macedonia and Achaia (6-10). In short, the Christians in Thessalonica have become imitators of Paul and Christ. The meaning of being imitators of Paul and Christ (or mediators) is spelt out in 1 Corinthians 4:16 or in Galatians 6:14 as an appeal to incarnate the gospel of the Cross of the Christ as it is exemplified by Paul's own life (Strüder 2005:393). Then follows Paul's autobiographical confession (2:1-12), including an interpolation that repeats what was already said in 1:1-10.

An autobiographical section (2:1-12) is interpolated between the first (1:1-10) and second thanksgiving (2:13-16). The second thanksgiving elaborates more on the motives of the first one. The work of faith (1:3) is qualified as the work of the word of God (2:13); the imitators of Paul and Jesus (1:6) are specified as imitators of the Judean Churches of God in Christ Jesus (2:14); the great affliction (1:6) is refined as the suffering that the Thessalonians had endured from their own countrymen and Jews (2:14). However, the two thanksgiving sections differ sharply by two contrastive endings. The first one ends on a note of satisfaction for the Thessalonians because of their achievements in faith, hope and love, conversion from idol worshipping, calm expectation of the parousia and deliverance from the wrath of God (1:7-10). On the other hand, the second thanksgiving ends on a bitter note, accusing the Jews not only of killing the Lord Jesus, but also displeasing God and opposing all men by hindering the spreading of the Gospel amongst the Gentiles. The final statement sounds as an approval of God's sentence on Jews: His wrath has come upon them (2:15-16).

The third section of thanksgiving (2:17-3:13) spells out the apostle's emotions about his physical separation from the 
Thessalonians (2:17-20) and his relation to Timothy's mission at Thessalonica (3:1-20). Paul expresses in vivid words his painful feelings about physical separation (e.g. 2:17-18: 'longing to seeing you face to face, but Satan hindered'). Yet, he is filled with hope and joy for those who have become his crown of boasting, joy and glory (2:17-20). Thanksgiving and joy motives explode in the narrative about Timothy's visit and his joy-provoking report. After describing on a sad note the state of worry and affliction before Timothy's mission (3:1-5), the narrative marks a change of mood by using the phrase arti de [but now]. Things have changed. Timothy has brought back good and affliction-releasing news about the Thessalonians' faith and love, as well as their yearning to see the apostle again face to face, altogether a great motive of thanksgiving and rejoicing and a motivation to continue praying night and day (3:6-10). Prayer and work are the only items that Paul recommends to be performed unceasingly $(2: 9 ; 3: 10)$. In this third section of thanksgiving, the need for continued prayer is felt and formulated in terms of petitions, requesting God to grant another opportunity for a face to face communion between Paul and the Thessalonians, as well as an increase in the faith of the latter. This shows that the Thessalonians' faith is not as ideal as it might appear from the rest of the letter, because 3:10 (cf. 4:10) indicates that there still is room for improvement. Immediately after this notice, follows a prayer of intercession (Collins 1990:776) imploring God to increase the love of Thessalonians for one another (communal love) and to all (universal love), in order to become irreproachable in holiness before God the father and on the parousia (3:11-13). As a matter of fact, 'blamelessness and holiness are qualities of fully realized eschatological existence' (Collins 1990:777; Bergant 2000:6). This communal and universal love with its eschatological significance argues against exclusive ethnocentrism (contra Malina \& Pilch 2006:11, 41).

The thanksgiving motif reappears once more at the closing section or final exhortations. This section specifies what needs to be improved in the life of the Thessalonians, that is, showing more and more love to each other and every one to mind their own business, to work with hands and so be able to command the respect of outsiders and depend on nobody (4:10-11). To sum up, Paul urges his audience to give thanks in everything, because that is the will of God for us in Christ Jesus (5:18). The thanksgiving motif in 5:18 constitutes an inclusio with the first motif of the thanksgiving in 1:2.

The thanksgiving motif is not to be confined only within the first three chapters of the letter (contra Lambrecht 1994c:336338). In view of this thanksgiving motif, prayer and work symbolise a committed way of giving thanks in words and deeds $(2: 9 ; 3: 10 ; 4: 10-12)$. 1 Thessalonians seems to thank God and praise his primary audience because of their work of faith. This work is to be understood in a holistic way, that is, a work that involves both spiritual and material dimensions. Spiritual aspects of this work of faith can be spelt out as the attitude of believing in the gospel of God and Jesus Christ. This faith nurtures other theological virtues of hope and love, as much as the latter reinforces the former on practical basis.
This faith also triggers the willingness to cultivate moral values and attitudes such as joy, prayer, endurance, purity, sanctification and peace. The material aspect of Pauline work of faith includes income generating work for self-reliance, for the sake of more effective and independent preaching. The work of faith, according to 1 Thessalonians, is not limited to the present time, but also involves an eschatological dimension in view of the second coming of Jesus.

If Africa has been portrayed as part of the commonwealth of poverty, the message of Paul for praying and working unceasingly appears to be an appropriate recommendation for fighting poverty in Africa today. Consequently, even the ordained ministers of the Word of God would cooperate to such a move if they carefully strive to distinguish between ministry and self-sustainability. Whilst the ministry should be regarded as a calling from God for a specific task in the broader field of evangelisation, the self-sustainability would not be pegged on the goodwill of the people to be evangelised, much less on the third parties. The minister, his mother church and his current audience are each invited to sustain themselves through income generating activities whilst carrying out their specific tasks of evangelisation. In fact, every Christian has to participate in preaching the Kingdom of God, but none should depend on others for carrying out his or her ministry, except for the sake of active solidarity where everybody is requested to contribute in promoting the welfare of the community. In this regard, the well spread practice whereby a Church pays her ministers for their evangelisation work or when the Church ministers financially assist their parishioners to meet their cost of living is not consistent with Pauline code of conduct (1 Th 2:9: 3:10; 4:10-12; 1 Cor 9:17-18; Ac 28:30-31). In Church history, this Pauline ideal of being a self-supportive preacher is partially achieved by monks and nuns who struggle as communities to perform their specific calling whilst managing to be financially independent. Some private Christian self-supportive learning and health centres could also be commendable if work and prayer are well balanced.

\section{The rhetoric of reconciliation ( 2 Cor 5:20)}

The multi-faceted violence in Africa underlines the need to promote a culture of peace. Paul's appeal for reconciliation (2 Cor 5:20) can contribute towards consolidating such a culture. Pauline theology of reconciliation is depicted to be both:

Objective and subjective, accomplished and applied, God's act and a person's state, extra nos and pro nobis, abstract and concrete, indicative and imperative, kerygmatic and parenetic, vertical and horizontal, already and not yet, personal and cosmic.

(Turner 1989:93; see also Bieringer 1994a:459, 1994b:510)

Without showing in detail how all these aspects are imbedded in 2 Corinthians 5:20 within its immediate and broader context (2 Cor 5:11-6:13), the present study focusses on this particular verse, which expresses more comprehensively Paul's teaching on reconciliation. The text of 2 Corinthians 5:20 can be restructured as follows:

a- huper Christou oun presbeuomen [on behalf of Christ then we are ambassadors] 
b- hos tou theou parakalountos di' hemon [as if God were exhorting through us]

c- deometha huper Christou [we beseech on behalf of Christ]

$\mathrm{d}$ - katallagète tô theô [be reconciled to God].

David L. Turner (1989:85) summarises the content of 2 Corinthians 5:20 as follows: 'As Christ's ambassador, and as the very mouthpiece of God, Paul pleads with the Corinthians in Christ's behalf to be reconciled to God.' This reconciliation has also been understood as 'Paul's appeal to the Corinthians to renew their peaceful relationship to God and his messenger' (Turner 1989:86; see also Furnish 1984:350; Martin 1986:155-156; Kruse 1987:128). More precisely, the verb presbeuomen (cf. Eph 6:10) describes Paul as an ambassador, a mediator, a representative or legate of a king carrying out diplomatic or governmental business (cf. 1 Macc 14:22; 2 Macc 11:34) (Turner 1989:85). But, Paul is the representative of Christ (a) and appeals on behalf of Christ $\left(a^{\prime}\right)$, as if God were exhorting the Corinthians through him (b) to let them be reconciled to God ( $\left.b^{\prime}\right)$. The literary structure of this verse can be presented as follows:

a- huper Christou oun presbeuomen [on behalf of Christ then we are ambassadors]

b-hos tou theou parakalountos $\mathrm{di}^{\prime}$ hemon [as if God were exhorting through us]

$\mathrm{a}^{\prime}$-deometha huper Christou [we beseech on behalf of Christ]

$b^{\prime}$-katallagète tô theô [be reconciled to God].

The chiastic construction of this verse revolves around the repetition of some key concepts. These include the phrase 'on behalf of Christ' [huper Christou] and Paul's mediations which are specified in terms of being an ambassador [presbeuomen] and pleading [deometha], as shown in the clauses $a$ and $a^{\prime}$. More importantly, the person of God is mentioned twice in $b$ and $b^{\prime}$ [ tou theou and to theô] together with the verb indicating his actions in exhorting [parakalountos] and reconciling [katallagète].

The combination of the passive voice, imperative mood and aorist aspect in the verb katallagète suggests that, (1) God is the ultimate subject of reconciliation, (2) the Corinthians are summoned to take part actively in the ministry of reconciliation and (3) to do this once and for all. Interpretations that focus only on passivum divinum undermine the appeal to human responsibility, as conveyed by the imperative form (cf. 1 Cor 7:11; Mt 5:24). Likewise, an interpretation that favours only the human activity tends to exclude God's initiative (Lambrecht 1994a:390-391, 412). Even if God had already reconciled the world (including the Corinthians) with himself through Christ, present circumstances compel the Corinthians to respond more responsibly and at once (imperative aorist). Indeed, 'the diakonos appeals to the people to take up the part that God assigned to them for completing the process of reconciliation' (Lambrecht 1994b:428).

Following a literary-functional equivalence method (Wendland 2004:32,45; Loba-Mkole 2008:262), an effort to bring out a meaning closer to the grammar of the original culture of 1 Corinthians 5:20d can be formulated as follows:
Let yourselves be reconciled at once to God by Himself. This is the core message of Paul's prayer and mediation on behalf of Christ [huper Christou]. The particle huper occurs 101 times in the Pauline corpus where it upholds the meaning 'on behalf of', except in Colossians 1:7 where it stands for 'instead of' (Caragounis 2004:527; see also Omanson 2006:411). The appeal 'katallagète tô theô' constitutes an important climax of Paul's exhortation to the Corinthians not only in verse 20 , but also in the whole speech on reconciliation (5:1-6:13). As Stanley E. Porter concludes in his study on 2 Corinthians 5:18-21:

In all, Paul describes God as the agent and the goal of reconciliation, in the sense that he is the one who initiates reconciliation and the one towards whom it is directed, all through or by means of the work of Christ.

(Porter 1996:705)

Paul's statement in 2 Corinthians 5:20 spells out in a unique way the vertical dimension of reconciliation, which has to start from the Corinthian community and moves to Paul, Christ and God. The immediate context explains why Paul, Christ and God are important in the reconciliation process of the Corinthians. God has already reconciled the world (including the Corinthians) to himself through Christ (v. 19). Here the phrase en Christô does not refer simply to the incarnation of God in Christ [theos en Christô], but to the entire life of Christ on earth by which God was reconciling the world to himself (Omanson 2006:362; Martin 1986:153155). Indeed, for the sake of the world (or for our own sake), God made Christ, who knew no sin, to be sin, so that in him we might become the righteousness of God (v. 21). Reconciliation and justification are closely related. As Ben Witherington III (1995:396) puts it, 'the degree that they [the Corinthians] are alienated from Paul, to that degree they are alienated from God'.

The rhetoric of reconciliation is developed in the whole section that deals with the ministry of reconciliation (2 Cor 5:11-6:13). This section constitutes a masterpiece of deliberative rhetoric. From the outset (v. 11), Paul makes clear that his modus operandi is to persuade, that is, to use the art of persuasion known as rhetoric. However, he is not using it just as a showy tool for proving his eloquence. Rather, his rhetoric is content-based, as he courageously asserts that he is known both before God and the Corinthian community (2 Cor 5:11). In all, he is controlled by the love of Christ, who died for all and through whom God has reconciled the world with him before entrusting the ministry of reconciliation to Paul. Objectively, the work of reconciliation has been achieved once and for all by God through Christ, but Paul is commissioned to remind the Corinthians that the subjective aspect of the reconciliation is still to be carried out on personal and community basis, and even at the level of the entire cosmos (2 Cor 5:11-19). Furthermore, Paul urges the Corinthians to take action here and now, whilst the time is favourable (2 Cor 6:1-2). He tactfully engages the Corinthian community in the reconciliation task, as he calls them his coworkers and shows them what he has already suffered for the sake of that ministry, but also because of his love for them (2 
Cor 6:3-13). Paul is carrying out his ministry of reconciliation not only because God entrusted it to him, but also out of love for Christ and for the Corinthians (2 Cor 5: 14; 6:11). As a matter of fact, 'the love of Christ' (Rm 8:5), made manifest when he died for all on the cross (2 Cor 5:14), remains the ultimate reference for all Christian behaviour (Denaux 1996:598). Like the philosophers of his time who used to list the trials they had overcome as proof of the excellence of their teaching, Paul regards his hardships as proof of the excellence of the gospel of God (compare 2 Cor 6:3-13 with 2 Cor 4:8-11). However, the fact that Paul is 'in difficulties on every side but never consumed' (2 Cor 4:8; cf. 2 Cor 11:16-33) also indicates the presence of God's power in him (2 Cor 1:810; 3:6-8; 4-13; 6:1-10; 12:1-12) (Matand 1997:184).

In a nutshell, 2 Corinthians 5:20d constitutes a climax of a fully fledged rhetoric of persuasion about reconciliation, an emphatic appeal and a parenetic milestone highly elaborated with the support of dogmatic arguments (2 Cor 5:11-19), followed by compelling and practical considerations (2 Cor 5:21-6:13). It is obvious that Africa today is in want of reconciliation. In such a situation, Paul becomes relevant because his core message to the Corinthians (1 Cor 5:20) is equally pertinent to Africa: If you are serious about reconciling with yourself, let yourself be reconciled to God by Himself.

\section{Conclusion}

Paul and Africa are mutually relevant to each other. The points of agreement between the two could be summarised as follows. Firstly, Africa needs to interact more actively with Paul to boost its human progress through constant prayer and work (1 Th 2:9; 3:10) whilst promoting the peace culture by letting itself be reconciled to God (2 Cor 5:20). Secondly, Paul still needs Africa to continue supporting his ministry of spreading the Gospel of Christ in the world. Thirdly, the mutual relevance between Paul and Africa is enshrined in the early Church traditions not only through the ministry support he received from African daughters and sons (cf. Ac 11:20; 1 Cor 3:5-6; 8-9; Rm 16:13), but also through the Third Council of Carthage (397) which included all the letters attributed to him as integral part of Canonical Scriptures. After all, Paul and many Africans belong to the same geographical environment of the Great Rift Valley Region.

\section{References}

Baur, J., 2005, 2000 Years of Christianity in Africa: An African Church History, 4th edn. Paulines, Nairobi.

Beardslee, A.W., 1961, Human Achievement and Divine Vocation in the Message of Paul, Alec R. Allenson, Nashville, TN.

Benjamin, J., 2001, 'Of Nubians and Nabateans: Implications or research on negleted dimensions of ancient world history', Journal of Asian and African Studies 36(4) 6-9, viewed 09 July 2008, from www.stcloudstate.edu/socialresponsability/ $6-9$, viewed 09 July
articles/nubians.asp)

Bieringer, R., 1994a, '2 Korinther 5,19a und die Versöhnung der Welt', in R. Bieringer \& J. Lambrecht (Hrsg.), Studies on 2 Corinthians, pp. 429-459, Leuven University Press, Leuven.

Bieringer, R., 1994b, Sünde und Gerichtigkeit Gottes in 2 Korinther 5,21, in R. Bieringer \& J. Lambrecht (Hrsg.), Studies on 2 Corinthians, pp. 461-513, Leuven University Press, Leuven.

Bieringer, R. (ed.), 1996, The Corinthian Correspondence, University Press, Leuven. Bieringer, R. \& Lambrecht, J., 1994, Studies on 2 Corinthians, University Press, Leuven.
Bonneau, N., 2005, 'Explorations du fait narratif et son effet théologique dans 1 Thessaloniciens [Explorations of a narrative fact and its theological effect in 1 Thessalonians]', in C. Focant \& A. Wénin (eds.), Analyse narrative et Bible, pp. Thessalonians]', in C. Focant \& A. Wénin (eds.
437-448, Leuven University Press, Leuven.

Brown, R.E., Fitzmyer, A.J. \& Murphy, E.R (eds.), 1990, The New Jerome Biblical Commentary, Prentice Hall, New Jersey, NJ.

Caragounis, C.C., 2004, The Development of Greek and the New Testament: Morphology, Syntax, Phonology, and Textual Transmission, Mohr Siebeck, Tübingen

Craffert, F.P., 2001, 'An Exercise in the Critical Use of Models: The "Goodness of Fit" of Wilson's Sect Model', in J.B. Malina \& J.J. Pilch (eds.), Social Scientific Models for Interpreting the Bible, pp. 21-46, Brill, Leiden.

Crossan, J.D. \& Reed, L.J., 2004, In Search of Paul: How Jesus's Apostle Opposed Rome's Empire with God's Kingdom. A New Vision of Paul's Words and World, HaperCollins, New York, NY.

Denaux, A., 1994, 'Theology and Christology in 1 Cor 8, 4-6: A Contextual-Redactional Reading', in R. Bieringer (ed.), The Corinthian Correspondence, pp. 593-606, Leuven University Press, Leuven.

Draman, R., 2003, 'Poverty and Conflict in Africa. Explaining a Complex Relationship', Experts Group Meeting on Africa-Canada Parliamentary Strengthening Program, Addis Ababa, Ethiopia, 19-23 May.

Dunn, J.D.G., 2009, New Testament Theology: An Introduction, Abingdon Press, Nashville, TN.

Du Toit, A., 2007, Focusing on Paul: Persuasion and Theological Design in Romans and Galatians, De Gruyter, Berlin, New York, NY.

Engbert-Petersen, T., 1995, Paul in his Hellenistic Context, Fortress, Minneapolis, MN.

Fitzmyer, A.J., 1990, 'Paul', in R.E. Brown et al. (eds.), The New Jerome Biblical Commentary, pp. 1329-1337, Prentice Hall, New Jersey, NJ.

Focant, C. \& Wénin, A., 2005, Analyse narrative et Bible [Narrative Analysis and the Bible], University Press, Leuven.

Furnish, V.P., 1984, 2 Corinthians, Doubleday, Garden City, KS.

Futehally, I., 2010, 'The Great Rift Valley', viewed 09 September 2010, from http:// EzineArticles.com/?expert=Ilmas_Futehally

Gilaerts, P. (ed.), 2004, Boanerges: Beschouwingen over bijbel (vertaling) en Retorica, Acco, Leuven.

Hock, F.R., 1976, 'Simon the Shoemaker as an Ideal Cynic', Greek, Roman and Byzantine Studies 17, 41-53.

Hock, F.R., 1978, 'Paul's Tentmaking and the Problem of His Social Class', Journal of Biblical Literature 97, 555-564. doi: 10.2307/3265397

Hock, F.R., 1979, 'The Work as a Social Setting for Paul's Missionary Preaching', Catholic Biblical Quarterly 41, 38-450.

Hock, F.R., 1980, The Social Context of Paul's Ministry: Tentmaking and Apostleship, Fortress, Philadelphia, PA.

Isichei, E., 1995, A History of Christianity in Africa: From Antiquity to the Present, SPCK, London.

Jewett, R., 2007, Romans: A Commentary, Fortress Press, Minneapolis, MN.

Kabasele-Mukenge, A. (ed.), 2010, Bible et promotion humaine [Bible and human development], Université Catholique du Congo - Médiaspaul, Kinshasa.

Kruse, C., 1987, The Second Epistle of Paul to the Corinthians, InterVarsity, Eerdmans, Grand Rapids, MI.

Lambrecht, J., 1994a, “"Reconcile Yourselves...” A Reading of 2 Corinthians 5, 11-21', in R. Bieringer \& J. Lambrecht (eds.), Studies on 2 Corinthians, pp. 363-412, Leuven University Press, Leuven.

Lambrecht, J., 1994b, 'Paul's Understanding of Diakonia in 2 Corinthians 5:18', in R. Bieringer \& J. Lambrecht (eds.), Studies on 2 Corinthians, pp. 413-428, Leuven, University Press, Leuven.

Lambrecht, J., 1994c, Pauline Studies: Collected Essays, Leuven, University Press, Leuven.

Légasse, S., 2002, L' épitre de Paul aux Romains [The letter of Paul to the Romans], Cerf, (Lectio Divina), Paris.

Loba-Mkole, J.-C., 2006, 'Ethics of a Business Manager. Intercultural Exegesis of Luke 16:1-18', Hekima Review 36, 51-70.

Loba-Mkole, J.-C., 2007, 'The New Testament and Intercultural Exegesis in Africa', Journal for the Study of the New Testament 30(1), 7-28. doi: $10.1177 / 0142064 \times 07081542$

Loba-Mkole, J.-C., 2008, 'History and Theory of Scripture Translations' HTS Teologiese Studies/Theological Studies 64(1), 253-266.

Loba-Mkole, J.-C., 2009, 'Just Wage and Poverty Alleviation: Intercultural Exegesis of Mt 20:1-16', in A. Kabasele (ed.), Bible et promotion humaine, pp. 189-207, Université Catholique du Congo - Médiaspaul, Kinshasa.

Martin, J.L., 1986, 2 Corinthians, Word, Waco, TX.

Malina, J.B., \& Pilch, J.J., 2006, Social-Science Commentary on the Letters of Paul, Fortress, Minneapolis, MN

Martin, P.M. \& O'Meara, P. (eds.), 1995, Africa, Indiana University Press, London.

Matand Bulembat, J.B., 1997, Noyau et enjeux de l'eschatologie paulinienne. De l'apocalyptique juive et de l'eschatologie hellénistique dans quelques argumentations de l'apôtre Paul. Etude rhétorico-exégétique de 1 Cor 15, 35argumentations de l'apotre Paul. Etude rhetorico-exégetique de 1 Cor 15, 35-
$58 ; 2$ Co 5,1-10 et Rm 8, 18-30 [Core Issues of the Pauline Eschatology. Jewish 58; 2 Co 5,1-10 et $\mathrm{Rm} 8,18-30$ [Core Issues of the Pauline Eschatology. Jewish
Apocalyptic and Hellenistic Eschatology in Some Argumentations of the Apostle Apocalyptic and Hellenistic Eschatology in Some Argumentations of the Apostle
Paul. Rhetorical and Exegetical Study of 1 Cor 15:35-58; 2 Cor 5:1-10 et Rm Paul. Rhetorical and Exegetical Study of 1 Cor 15:35-58; 2
8:18-30], Walter de Gruyter, Berlin, New York, NY. (BZNW 84). 
McCant, W.J., 1988, 'Paul's Thorn of Rejected Apostleship', New Testament Studies 34(4), 550-572. doi: 10.1017/S0028688500021123

McNulty, L.M., 1995, 'The Contemporary Map of Africa', in P.M. Martin \& P. O'Meara (eds.), Africa, pp. 10-48, Indiana University Press, London.

Mugambi, J.N.K., 1995, From Liberation to Reconstruction, EAE Publishers, Nairobi.

Mulholland, D., Loba-Mkole, J.-C. \& Kitoko, N., 2009, Philemon: Fellowship in God's Family, Sapientia Publishers, Pretoria.

Murphy-O'Connor, J., 1996, Paul: A Critical Life, University Press, Oxford.

Ndaywel è Nziem, I., 1998, Histoire générale du Congo: De l'héritage ancien a la République Démocratique [General History of Congo: From the Ancient Heritage to the Democratic Republic], Duculot, Paris, Bruxelles.

Nyamiti, C., 2007, Studies in African Christian Theology. Vol. 3: Some Contemporary Models of African Ecclesiology: A Critical Assessment in the Light of Biblical and Church Teaching, The Catholic University of Eastern Africa, Nairobi.

Omanson, L.R., 2006, A Textual Guide to the Greek New Testament: An Adaptation of Bruce M. Metzger's Textual Commentary for the Needs of Translators, German Bible Society, Stuttgart.

Orobator, A.E., 2005, From Crisis to Kairos. The Mission of the Church in the Time of HIV/AID, Refugees and Poverty, Paulines, Nairobi.

Pilch, J.J. (ed), 2001, Socioal Scientific Models for Interpreting the Bible: Essays by the Context Group in Honour of Bruce J. Malina, Brill, Leiden-Boston-Köln.

Porter, E.S., 1996, 'Reconciliation and 2 Cor 5, 18-21', in R. Bieringer (ed.), The Corinthian Correspondance, pp. 693-705, Leuven University Press, Leuven.

Ramsay, M.W. \& Wilson, M., 2001, St Paul the Traveler and Roman Citizen: Full-Color Updates \& Revised $15^{\text {th }}$ Edition, Grand Rapids, MI, London.

Rengstorf, K.H., 1964, 'Apostolos' in G. Kittel (ed.), Theological Dictionary of the New Testament, pp. 407-447, Eerdmans, Grand Rapids, MI.
Shorter, A., 2000, 'Violence: Causes and Responses', in J.G. Wanjohi \& G.W. Wanjohi (eds.), Social and Religious Concerns of East Africa, pp. 344-349, Paulines Publications, Washington, DC

Still, D.T., 2006, 'Did Paul Loathe Manual Labor? Revisiting the Work of Ronald F. Hock on the Apostle's Tentmaking and Social Class', Journal of Biblical Literature 125(4), 781-795. doi: $10.2307 / 27638405$

Strüder, C.W., 2005, Paulus und die Gesinnung Christi. Identität und Entscheidungsfindung aus der Mitte von 1 Kor 1-4, Leuven University Press, Leuven.

Turner, L.D., 1989, 'Paul and the ministry of Reconciliation in 2 Cor 5:11-6:2', Criswell Theological Review 4(1), 77-95.

Van Aarde, A., 2007, 'Jesus' Mission to All of Israel Emplotted in Matthew', Neotestamentica 41(2), 416-432.

Van Binsbergen, W., 2003, Intercultural Encounters: African and Anthropological Lessons towards a Philosophy of Interculturality, LIT, Münster.

Van lersel, B.M.F., 1998, Mark: A Reader-Response Commentary, Academic Press, Sheffield.

Van Segbroeck, F., 2004, "'Niet alleen door onze woorden": Retoriek in 1 Tessaloniecenzen?', in P. Gillaerts (red.), Boanerges, pp. 87-101, Acco, Leuven.

Van den Heever, G. \& Scheffler, E., 2001, From Jesus Christ to Christianity: Early Christian Literature in Context, University of Pretoria, Pretoria.

Van der Watt, J.G., 2000, The Family of the King: Dynamics of Metaphor in the Gospe according to John, Brill, Leiden-Boston-Köl.

Wanjohi, J.G. \& Wanjohi, G.W. (eds.), 2005, Social and Religious Concerns of East Africa, Wajibu, Nairobi.

Wendland, R.E., 2004, Translating the Literature of Scripture: A Literary-rhetorical Approach to the Bible Translation, SIL International, Dallas, TX.

Witherington III, B., 1995, Conflict and Community in Corinth: A socio-Rhetorical Commentary on 1 and 2 Corinthians, Eerdmans, Grand Rapids, MI. 